\title{
Using white cement as a source of calcium oxide in Anorthite body
}

\author{
Ali Arastehnodeh ${ }^{1} \cdot$ Majid Saghi $^{2}$ \\ Received: 11 October 2017 / Accepted: 11 February 2018 / Published online: 26 February 2018 \\ (c) The Author(s) 2018. This article is an open access publication
}

\begin{abstract}
Anorthite is a rare compositional variety of plagioclase. This mineral is a type of calcium-rich plagioclase feldspar which has great properties such as low thermal expansion coefficient and high modulus of rupture. Therefore, physical properties of hard porcelain bodies will be improved by creating anorthite phase. According to limitation of anorthite natural sources, various sources were used to synthesis of anorthite. In this paper, white cement was introduced as a new calcium oxide source to reach anorthite phase. For this purpose, a standard composition for hard porcelain was prepared by addition of $50 \mathrm{wt} \%$ kaolin, $25 \mathrm{wt} \%$ potassium feldspar and $25 \mathrm{wt} \%$ quartz. Six additional body mixtures were formulated partially by replacing $0,3,4.5,6,7.5$ and $9 \mathrm{wt} \%$ of potassium feldspar by white cement. The linear shrinkage, water adsorption, modulus of rapture (M.O.R), and bulk density of fired body were calculated. Phase characterization was accomplished by X-ray diffractometer (XRD) and scanning electron microscopes. By replacing potassium feldspar with white cement, anorthite was appearance in fired body at $1250{ }^{\circ} \mathrm{C}$. This replacing decreases bulk density, linear shrinkage and modulus of rapture. Although, water adsorption and consequently firing temperature increase by replacing white cement but $1250{ }^{\circ} \mathrm{C}$ was a good temperature for firing replaced bodies.
\end{abstract}

Keywords White cement $\cdot$ Hard porcelain $\cdot$ Anorthite $\cdot$ Calcium source

\section{Introduction}

Porcelains are one of the most important glazed or unglazed vitrified whitewares which contain ternary compound of kaolin, feldspar and quartz [1]. Kaolin is an aluminosilicate mineral that includes $\left[\mathrm{Si}_{2} \mathrm{O}_{5}\right]^{2-}$ and $\left[\mathrm{Al}_{2}(\mathrm{OH})_{4}\right]^{2+}$ layers which provide plasticity and green strength during shaping process. Feldspar is used as flux in porcelain industries to reduce firing temperature and make glass phase and quartz is used as filler which is effective on the reduction of pyroplastic deformation through firing process [2]. During firing process, free quartz and mullite are formed and distributed in glassy matrix and fired body reach to maximum density between 1250 and $1300{ }^{\circ} \mathrm{C}$ [1-4]. Most properties of hard porcelain bodies depend on glassy matrix homogeneity [3], pores (size, shape and distribution) [2], and

Ali Arastehnodeh

aliarastehnodeh@iauq.ac.ir

1 Chemical Engineering Department, Quchan Branch, Islamic Azad University, Quchan, Iran

2 Young Researchers and Elite Club, Arak Branch, Islamic Azad University, Arak, Iran type of crystals. Difference of density, refractive index and thermal expansion coefficient of crystals and glass phase were caused to change the whiteware's strength and translucency of fired body. Because of high crystalline to glassy phase ratio, this whiteware body has higher mechanical strength ( $100 \mathrm{MPa})$ and in spite of this, compare to hard porcelain, bone china has better whiteness and translucency [5-7]. Bone china composition includes tri-calcium phosphate, anorthite, quartz and glassy phases [8]. Similar reflective index with glassy phase causes more translucencies. Furthermore, thermal expansion coefficient (TEC) of anorthite $\left(\sim 4.3 \times 10^{-6} \mathrm{~K}^{-1}\right)$ closed to glassy phase $\left(\sim 3-4.5 \times 10^{-6} \mathrm{~K}^{-1}\right)$, which makes it resistance to thermal shock but TEC of tri-calcium phosphate $\left(\sim 12 \times 10^{-6} \mathrm{~K}^{-1}\right)$ [9], increases TEC of bone china $\left(\sim 8.5 \times 10^{-6} \mathrm{~K}^{-1}\right)$ [8] and makes it suitable for low-temperature glaze [9]. These two appropriate properties of anorthite encouraged the producer to improve physical properties of hard porcelain bodies by creating anorthite phase in body [10]. Capoghlu investigated to produce translucent whiteware with anorthite, mullite and a small amount of glassy phase [11]. Furthermore, he increased the whiteness of porcelain body using new composition includes wollastonite, alumina, ball clay and quartz. 
Taskiran and colleagues reported that high ratio of crystalline phase which included 50\% anorthite to glassy phase (70/30) is caused by high flexural strength [12]. Anorthite is one of the main members of plagioclase feldspar family [13]. According to limited natural anorthite sources [14], scientists strive to synthesize it by difference methods such as sol-gel [15], sintering the mixture of raw materials [16] and mechanochemical method [17]. Due to the high melting temperature of anorthite, several studies were carried out to decrease the crystallization of anorthite using different fluxing agents such as boron, $\mathrm{Na}_{2} \mathrm{CO}_{3}$ and some other additives [17-19]. Supplementary scientists investigate about various calcium sources to reach anorthite phase in porcelain bodies. They used $\mathrm{Ca}(\mathrm{OH})_{2}$, calcite, marble powder and gypsum mold waste [20], dolomite, wollastonite and calcite [21]. In this research, white cement was used as a new $\mathrm{CaO}$ source for anorthite base porcelains and its influence on sintering behavior, M.O.R, TEC, bulk density, and water adsorption were investigated.

\section{Materials and methods}

The raw materials used in this investigation were kaolin (Super Standard Porcelain, IMERYS Ceramics, UK), quartz (Morvarid-Iran), potassium feldspar (Quantum AP200F, Cibelco-India) and white cement. The chemical compositions of raw materials were determined by X-ray fluorescence (XRF) analyzer (PANalytical, Axios model) (Table 1). A standard composition for hard porcelain was prepared by

Table 1 The chemical composition of raw materials

\begin{tabular}{lllll}
\hline $\begin{array}{l}\text { Composition } \\
(w t \%)\end{array}$ & Kaolin & K-feldspar & Quartz & White cement \\
\hline $\mathrm{SiO}_{2}$ & 47.1 & 64.9 & 99.15 & 19.9 \\
$\mathrm{Al}_{2} \mathrm{O}_{3}$ & 37.1 & 17 & 0.68 & 3.94 \\
$\mathrm{Fe}_{2} \mathrm{O}_{3}$ & 0.7 & 0.28 & 0.03 & 0.38 \\
$\mathrm{CaO}$ & 0.26 & 0.76 & 0.12 & 59.2 \\
$\mathrm{MgO}$ & 0.33 & 0.44 & - & 0.61 \\
$\mathrm{Na}_{2} \mathrm{O}$ & - & 2.42 & - & 1.22 \\
$\mathrm{~K}_{2} \mathrm{O}$ & 1.87 & 12.1 & - & 0.69 \\
L.O.I. & 12.4 & 0.57 & - & - \\
\hline
\end{tabular}

addition of $50 \mathrm{wt} \%$ kaolin, $25 \mathrm{wt} \%$ potassium feldspar and $25 \mathrm{wt} \%$ quartz.

Six additional body mixtures were formulated partially by replacing $0,3,4.5,6,7.5$ and $9 \mathrm{wt} \%$ of potassium feldspar by white cement. In Table 2, the composition of specimens has been listed.

The slips of $S_{0}, S_{3}, S_{4.5}, S_{6}, S_{7.5}$ and $S_{9}$ were prepared by milling $2000 \mathrm{~g}$ of the mixtures with $3000 \mathrm{~g}$ water for $8 \mathrm{~h}$ in a jar mill. The resulting watery slurries were passed through a $100-\mu \mathrm{m}$ sieve, deironing by a permanent magnet, and dewatered on a plaster plate. Finally, the resulted mud was extruded into $2 \mathrm{~cm} \times 1 \mathrm{~cm} \times 10 \mathrm{~cm}$ bars. The bars were first air-dried at room temperature for $24 \mathrm{~h}$ and then oven-dried at $100 \pm 5{ }^{\circ} \mathrm{C}$ for $2 \mathrm{~h}$. After drying, the samples were fired at $1020,1100,1195,1250$, and $1340{ }^{\circ} \mathrm{C}$ in electric kiln (Exciton, EX-1700 model). The linear shrinkage, water adsorption (ASTM C373-88) and bulk density of fired body were calculated by densitometer (Sartorious, LA230S model; Germany). Phase characterization was accomplished by a DX-27 mini X-ray diffractometer (XRD) using $\mathrm{Cu} \mathrm{K} \alpha$ radiation and operating at $40 \mathrm{kV}$ and $30 \mathrm{~mA}$. For this purpose, bulk sample were scanned in the angle range of $2 \theta$ : $4-70^{\circ}$. Modulus of rupture of the samples was measured by NETZSCH-Geratebau bending strength tester 40. Finally, Cambridge S360 analytical scanning electron microscopes run at $19.9 \mathrm{kV}$ to study the microstructure of these two samples. Gold coating of the samples was carried out using a Sputter-coating instrument.

\section{Results and discussion}

In all firing temperature, linear shrinkage of samples decreased by cement content (see Fig. 1). Besides, increasing the firing temperature increases the amount of liquid phase which fills the pores and causes to increase the linear shrinkage.

Water adsorption and bulk density as function of cement content at various temperatures were showed in Figs. 2 and 3 , respectively. According to results of linear shrinkage, as one expect water adsorption increases by addition of white cement. Whereas the reduction of firing temperature was cause to increase water adsorption.

The water adsorption values of fired specimens at 1250 and $1340{ }^{\circ} \mathrm{C}$ for all samples were zero which was due to
Table 2 Composition of specimens

\begin{tabular}{lcccccc}
\hline Composition (wt\%) & $S_{0}$ & $S_{3}$ & $S_{4.5}$ & $S_{6}$ & $S_{7.5}$ & $S_{9}$ \\
\hline Kaolin & 50 & 50 & 50 & 50 & 50 & 50 \\
Quartz & 25 & 25 & 25 & 25 & 25 & 25 \\
K-Feldspar & 25 & 22 & 20.5 & 19 & 17.5 & 16 \\
White cement & - & 3 & 4.5 & 6 & 7.5 & 9 \\
\hline
\end{tabular}




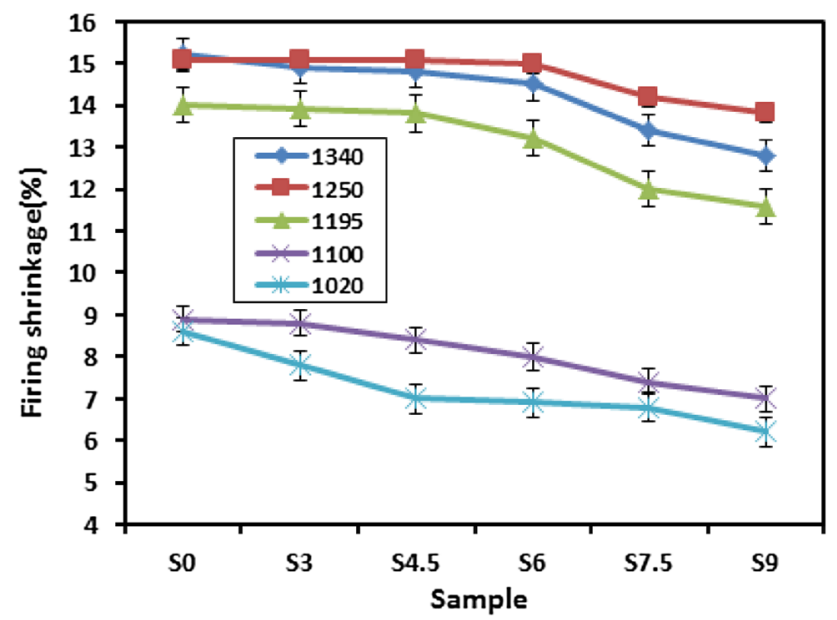

Fig. 1 Linear shrinkage of fired samples at different temperatures $\left({ }^{\circ} \mathrm{C}\right)$

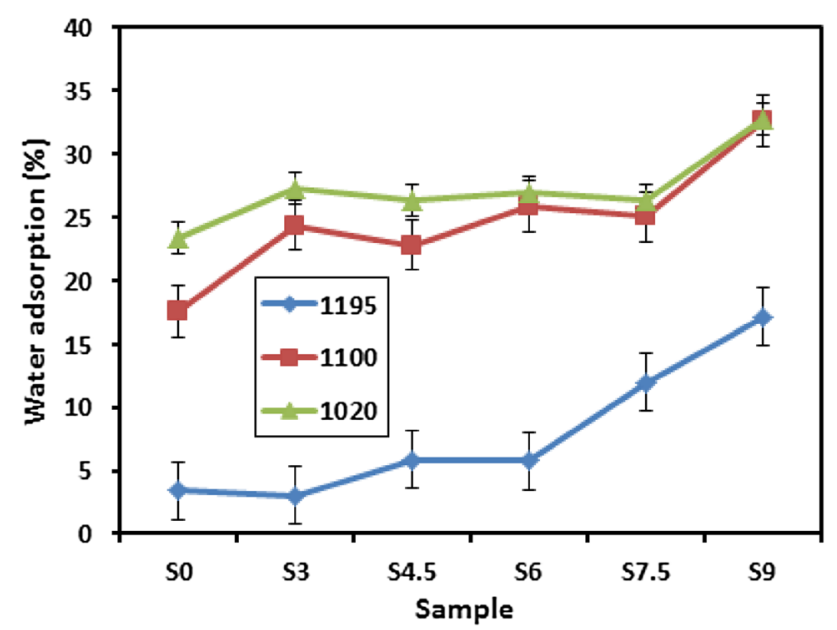

Fig. 2 Water adsorption of fired samples at different temperatures $\left({ }^{\circ} \mathrm{C}\right)$

complete sintering. At the other temperatures, water adsorption values decreased by white cement content. According to high viscosity of glass phase due to presence of white cement, water adsorption was increased at $1195{ }^{\circ} \mathrm{C}$ by increasing white cement content. Water adsorption has direct relevance of porosity and the porosity has inverse relationship with the bulk density; therefore, it is obvious that bulk density increases by increasing the firing temperature for $\mathrm{S}_{0}$ body. In other bodies, the bulk density decreases after $1250{ }^{\circ} \mathrm{C}$, and also it decreases by adding white cement in the composition, this suggests decreased density of the body as a result of development of glass phase or development of a bubble in the fired body [22]. Furthermore, the specimens that fired at $1250{ }^{\circ} \mathrm{C}$ reached the maximum value of bulk density that implies full sintering at this temperature.

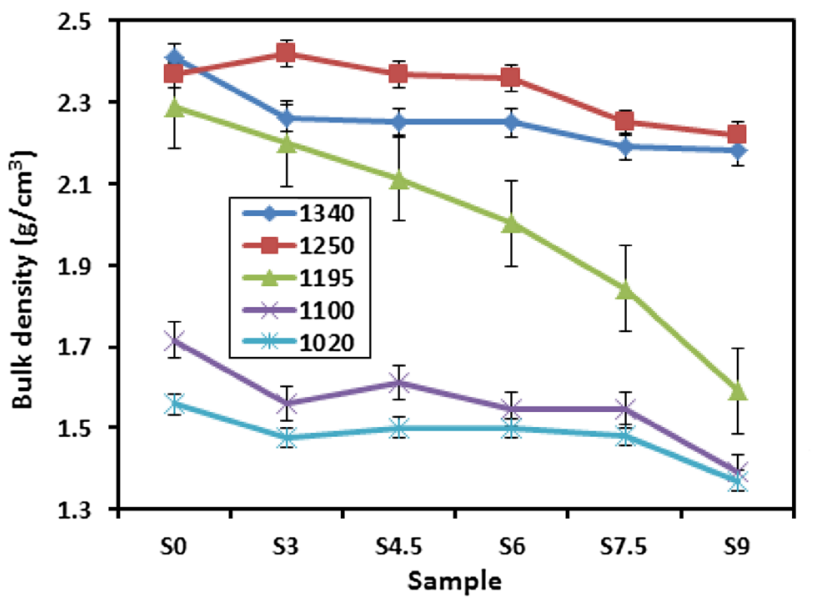

Fig. 3 Bulk density of fired samples at different temperatures $\left({ }^{\circ} \mathrm{C}\right)$

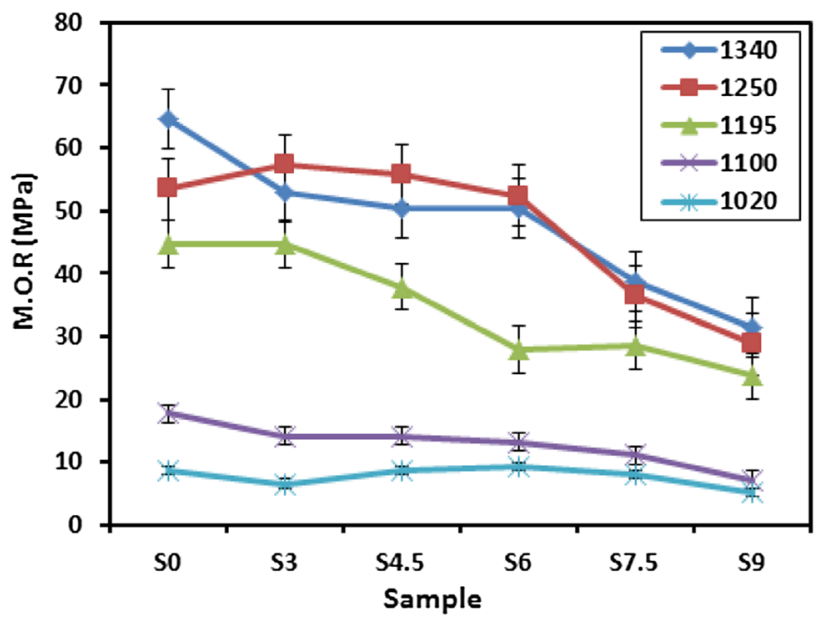

Fig. 4 Modulus of rupture of fired samples at different temperatures $\left({ }^{\circ} \mathrm{C}\right)$

Bulk density of fired specimens at 1020,1100 and $1195^{\circ} \mathrm{C}$ reduces corresponding increasing water adsorption. Bulk density of samples with various amounts of cement which were fired at $1250{ }^{\circ} \mathrm{C}$ is similar to bulk density of fired sample at $1340{ }^{\circ} \mathrm{C}$ without any cement. According to these results, $\mathrm{CaO}$ play a main role during firing process. In fact, $\mathrm{CaO}$ increase the surface tension of glassy phase which could be due to reduction of density. Figure 4 shows modulus of rupture of specimens (M.O.R) as function of the amount of cement at different firing temperatures. Behavior of specimens which were fired at $1020{ }^{\circ} \mathrm{C}, 1100$ and $1195{ }^{\circ} \mathrm{C}$ fits perfectly with the bulk density values. At these temperatures, as one would expect, modulus of rupture of samples decreases with decreasing firing temperature and also decreases with adding white cement. It is to be noted that severe loss of modulus of rupture of the samples with 
more than $6 \%$ white cement can be seen. It might be because of sudden increasing of glassy phase. White cement provides more $\mathrm{CaO}$ beside $\mathrm{SiO}_{2}$ in glassy phase.

Modulus of rupture values for fired samples at $1250{ }^{\circ} \mathrm{C}$ with 3, 4.5 and 6 percent white cement is more than the fired samples at $1340{ }^{\circ} \mathrm{C}$, whereas before adding white cement fired sample at $1340{ }^{\circ} \mathrm{C}$ has higher modulus of rupture. Also adding more than $6 \%$ white cement leads to decrease modulus of rupture of both. Reduction of modulus of rupture of fired sample at $1340{ }^{\circ} \mathrm{C}$ in the presence of white cement might be because of over firing, bloating and deformation of specimens. As previously mentioned, more than $6 \%$ white cement might be leads to increase glassy phase. Figures 5 and 6 show XRD patterns of $S_{0}, S_{4.5}$ and $S_{9}$ that fired at 1340 and $1250{ }^{\circ} \mathrm{C}$.

No anorthite phase exists in the structure of fired samples at $1340{ }^{\circ} \mathrm{C}$ except the sample which contained $9 \mathrm{wt} \%$ white cement. However, XRD patterns of fired samples at $1250{ }^{\circ} \mathrm{C}$ show anorthite peaks. Previous studies [16] reported that maximum amount of anorthite phase was formed between 1170 and $1245{ }^{\circ} \mathrm{C}$. It seems that anorthite phase was melted and dissolved in glass phase by increasing temperature from 1250 to $1340{ }^{\circ} \mathrm{C}$. These results were proved in SEM picture (Fig. 7). The thermal expansion coefficient of porcelain body is a key factor when considering the thermal match between body and glaze. According to thermal expansion coefficients, the average TEC of the samples between room temperature and $600{ }^{\circ} \mathrm{C}$ is calculated and listed in Table 3. Anorthite phase formation with low thermal expansion coefficient

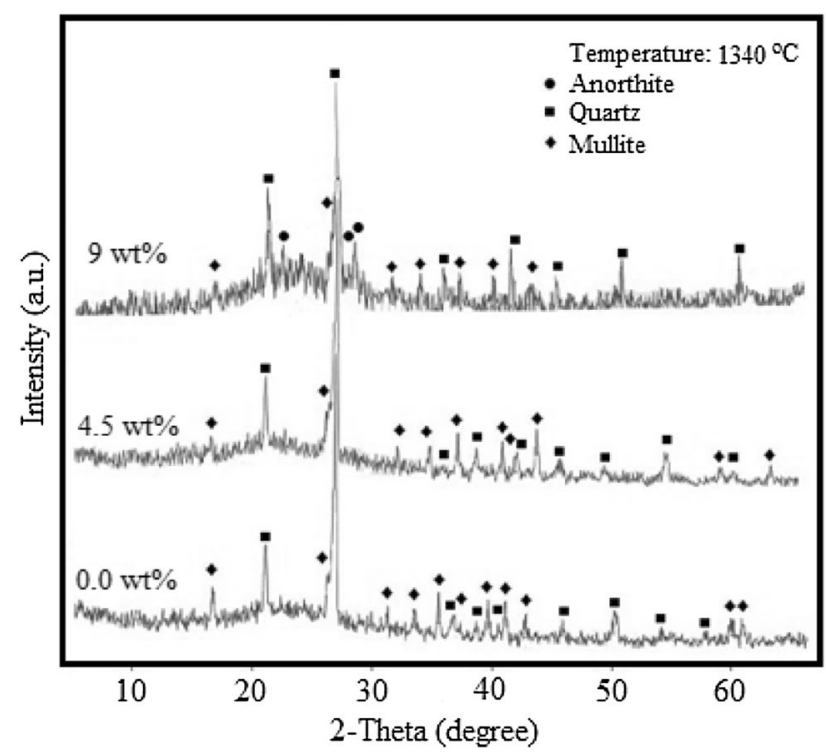

Fig. 5 XRD patterns of fired $S_{0}, S_{4.5}$ and $S_{9}$ at $1340{ }^{\circ} \mathrm{C}$

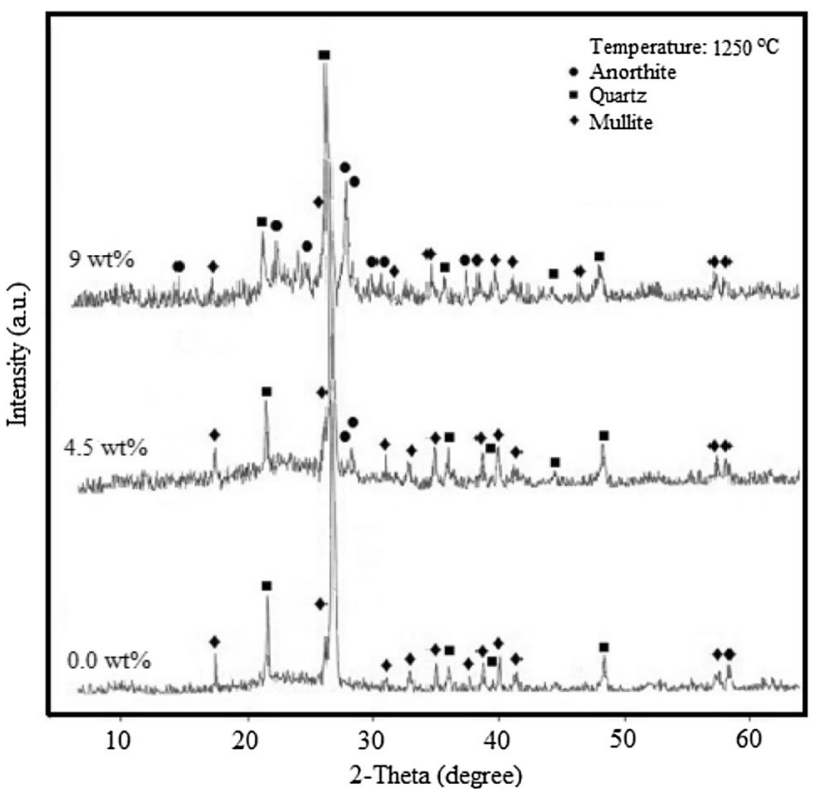

Fig. 6 XRD patterns of fired $S_{0}, S_{4.5}$ and $S_{9}$ at $1250{ }^{\circ} \mathrm{C}$

would be cause to decrease TEC of body. According to Table 3, TEC decrease by addition of white cement. This low TEC confirms that anorthite base porcelain would be resistant to thermal shock.

White cement increased $\mathrm{CaO}$, which decreased the linear shrinkage rate. It is because of the amount of glassy phase. In these circumstances, the water adsorption was directly related to temperature rising and also it was inversely correlated with increasing the amount of $\mathrm{CaO}$. The bulk density had the same behavior. $\mathrm{CaO}$ caused increasing surface tension of glassy phase so the bulk density decreased. It should be noted that $\mathrm{CaO}$ addition more than $6 \%$ especially at higher temperatures was leading to sudden increase the amount of glassy phase.

\section{Conclusions}

By replacing potassium feldspar with white cement, anorthite appeared in fired body at $1250{ }^{\circ} \mathrm{C}$. This crystal can be seen in fired body at $1340{ }^{\circ} \mathrm{C}$ replacing $9 \%$ potassium feldspar with white cement. Replacing white cement and constitution of anorthite caused decreasing linear shrinkage. This replacing decreases bulk density, linear shrinkage and modulus of rapture. Although water adsorption and consequently firing temperature increase by replacing white cement, $1250{ }^{\circ} \mathrm{C}$ was a good temperature for firing replaced bodies. 
Fig. 7 SEM images of fired bodies (a $S 9$ fired at $1340{ }^{\circ} \mathrm{C}$; b $S 0$ fired at $1340{ }^{\circ} \mathrm{C}$; c $S 9$ fired at $1250{ }^{\circ} \mathrm{C}$; d $S 0$ fired at $1250{ }^{\circ} \mathrm{C}$ )
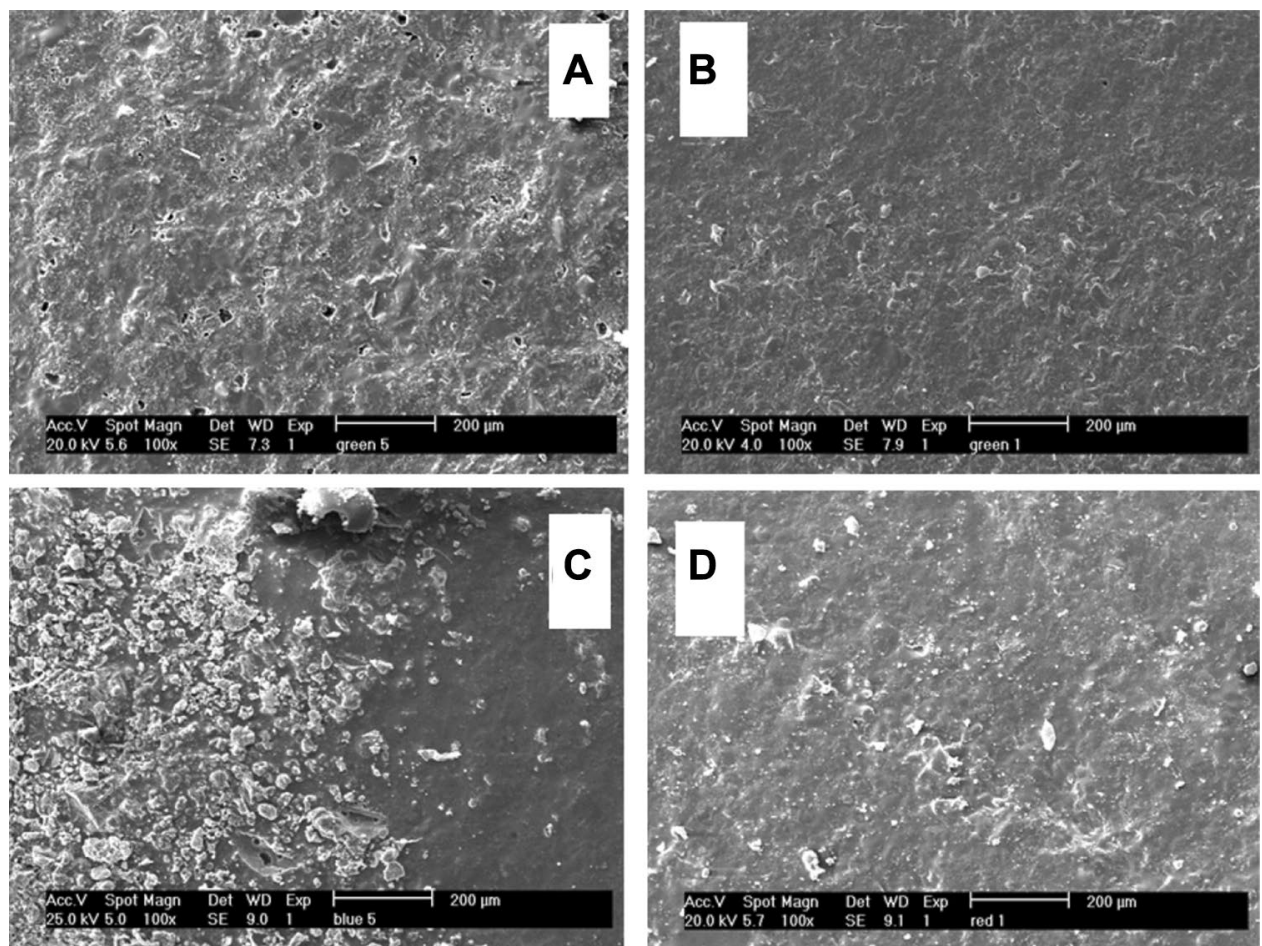

Table 3 Average TEC values of samples measured in the range from 25 to $600{ }^{\circ} \mathrm{C}$

\begin{tabular}{|c|c|c|c|c|c|c|c|c|}
\hline \multirow[t]{3}{*}{ Temperature $\left({ }^{\circ} \mathrm{C}\right)$} & \multicolumn{8}{|c|}{ Thermal expansion coefficient, $\alpha \times 10^{-6} \mathrm{~K}^{-1}$} \\
\hline & \multicolumn{4}{|l|}{$1250^{\circ} \mathrm{C}$} & \multicolumn{4}{|c|}{$1340^{\circ} \mathrm{C}$} \\
\hline & $S_{0}$ & $S_{4.5}$ & $S_{6}$ & $S_{7.5}$ & $S_{0}$ & $S_{4.5}$ & $S_{6}$ & $S_{7.5}$ \\
\hline $25-100$ & 5.1932 & 4.2327 & 4.1872 & 4.1661 & 4.5047 & 4.354 & 4.2193 & 4.2098 \\
\hline 100-200 & 5.6889 & 4.9835 & 4.8876 & 4.7307 & 5.324 & 4.9953 & 4.918 & 4.7915 \\
\hline $200-300$ & 6.1479 & 5.3755 & 5.2114 & 5.1821 & 5.5183 & 5.3334 & 5.2421 & 5.2231 \\
\hline $300-400$ & 6.6729 & 5.8597 & 5.8016 & 5.4836 & 6.0361 & 5.8933 & 5.612 & 5.5101 \\
\hline $400-500$ & 7.5255 & 6.3654 & 6.2114 & 5.8442 & 6.7346 & 6.4815 & 6.2721 & 5.9817 \\
\hline $500-600$ & 11.0457 & 8.2882 & 8.0088 & 7.5292 & 9.168 & 8.3417 & 8.1651 & 7.8142 \\
\hline
\end{tabular}

Acknowledgements We are grateful to Maghsoud porcelain Co. for financial assistance.

Open Access This article is distributed under the terms of the Creative Commons Attribution 4.0 International License (http://creativecommons.org/licenses/by/4.0/), which permits unrestricted use, distribution, and reproduction in any medium, provided you give appropriate credit to the original author(s) and the source, provide a link to the Creative Commons license, and indicate if changes were made.

\section{References}

1. Carty WM, Senapati U (1998) Porcelain-raw materials, processing, phase evolution, and mechanical behavior. J Am Ceram Soc 81:3-20. https://doi.org/10.1111/j.1151-2916.1998.tb02290.x
2. Kobayashi Y, Ohira O, Ohashi Y, Kato E (1992) Effect of firing temperature on bending strength of porcelains for tableware. J Am Ceram Soc 75:1801-1806. https://doi. org/10.1111/j.1151-2916.1992.tb07200.x

3. Ece OI, Nakagawa Z (2002) Bending strength of porcelains. Ceram Int 28:131-140. https://doi.org/10.1016/S0272 -8842(01)00068-2

4. Braganca SR, Bergmann CP (2003) A view of whitewares mechanical strength and microstructure. Ceram Int 29:801-806. https://doi.org/10.1016/S0272-8842(02)00234-1

5. Ustundag CB, Tur YK, Capoglu A (2006) Mechanical behaviour of a low-clay translucent whiteware. J Eur Ceram Soc 26:169177. https://doi.org/10.1016/j.jeurceramsoc.2004.10.019

6. Batista SAF, Messer PF, Hand RJ (2001) Fracture toughness of bone china and hard porcelain. Br Ceram Trans 100:256-259. https://doi.org/10.1179/bct.2001.100.6.256

7. Pierre PDSST (1954) Constitution of bone china: I, high-temperature phase equilibrium studies in the system tricalcium 
Phosphate-Alumina-Silica. J Am Ceram Soc 37:243-258. https ://doi.org/10.1111/j.1151-2916.1954.tb14033.x

8. Capoglu A (2005) Elimination of discolouration in reformulated bone china bodies. J Eur Ceram Soc 25:3157-3164. https://doi. org/10.1016/j.jeurceramsoc.2004.07.008

9. Iqbal Y, Messer PF, Lee WE (2000) Non-equilibrium microstructure of bone china. Br Ceram Trans 99:110-116. https:// doi.org/10.1179/096797800680811

10. Capoglu A (2011) A novel low-clay translucent whiteware based on anorthite. J Eur Ceram Soc 31:321-329. https://doi. org/10.1016/j.jeurceramsoc.2010.10.004

11. Capoglu A, Messer PF (2004) Design and development of a chamotte for use in a low-clay translucent whiteware. J Eur Ceram Soc 24:2067-2072. https://doi.org/10.1016/S0955-2219(03)00359-5

12. Taskiran MU, Demirkol N, Capoglu A (2005) A new porcelainised stoneware material based on anorthite. J Eur Ceram Soc 25:293300. https://doi.org/10.1016/j.jeurceramsoc.2004.03.017

13. Sutcu M, Akkurt S (2010) Utilization of recycled paper processing residues and clay of different sources for the production of porous anorthite ceramics. J Eur Ceram Soc 30:1785-1793. https://doi. org/10.1016/j.jeurceramsoc.2010.01.038

14. Cheng X, Ke S, Wang Q, Wang H, Shui A, Liu P (2012) Fabrication and characterization of anorthite-based ceramic using mineral raw materials. Ceram Int 38:3227-3235. https://doi.org/10.1016/j. ceramint.2011.12.028

15. Hong SH, Young JF, Yu P, Kirkpatrick RJ (1999) Synthesis of anorthite by the Pechini process and structural investigation of the hexagonal phase. J Mater Res 14:1828-1833. https://doi. org/10.1557/JMR.1999.0246

16. Kobayashi Y, Kato E (1994) Low-temperature fabrication of anorthite ceramics. J Am Ceram Soc 77:833-834. https://doi. org/10.1111/j.1151-2916.1994.tb05373.x
17. Baran B, Sarikaya Y, Alemdaroglu T, Onal M (2003) The effect of boron containing frits on the anorthite formation temperature in kaolin-wollastonite mixtures. J Eur Ceram Soc 23:2061-2066. https://doi.org/10.1016/S0955-2219(03)00032-3

18. Pierre PDSST (1956) Constitution of bone china: III, high-temperature phase equilibrium studies in the system tricalcium phosphate Anorthite-Silica. J Am Ceram Soc 39:147-150. https://doi. org/10.1111/j.1151-2916.1956.tb14181.x

19. Kavalci S, Yalamac E, Akkurt S (2008) Effects of boron addition and intensive grinding on synthesis of anorthite ceramics. Ceram Int 34:1629-1635. https://doi.org/10.1016/j.ceramint.2007.07.007

20. Kurama S, Ozel E (2009) The influence of different $\mathrm{CaO}$ source in the production of anorthite ceramics. Ceram Int 35:827-830. https://doi.org/10.1016/j.ceramint.2008.02.024

21. Ke S, Cheng X, Wang Y, Wang Q, Wang H (2013) Dolomite, wollastonite and calcite as different $\mathrm{CaO}$ sources in anorthite-based porcelain. Ceram Int 39:4953-4960. https://doi.org/10.1016/j. ceramint.2012.11.091

22. Nodeh AA (2017) Influence of bone porcelain scraps on the physical characteristics and phase composition of a hard porcelain body. Boletín de la Sociedad Española de Cerámica y Vidrio 56:113-118. https://doi.org/10.1016/j.bsecv.2017.04.003

Publisher's Note Springer Nature remains neutral with regard to urisdictional claims in published maps and institutional affiliations. 